\title{
ANDREW MULHOLLAND, alias GEORGE WILSON
}

\author{
By H. J. Mantz \\ Justice, Iowa Supreme Court
}

Some years following the turn of the century, a situation arose in western Iowa, which was packed with dramatic incidents. Courts were resorted to and litigation followed. The facts and chain of events, their ramifications, the period of time covered, all combined to create a sort of human drama, which well might be set forth in a novel. The chain of events started a few years prior to the Civil war, and did not terminate until about the end of the first quarter of the present century. To some of the events the writer was an eye witness. He secured some information from court records, some from the principal actor, and some from those who were associated with him in the incidents which fit into the pattern of what took place.

After the litigation, and as we sometimes say "the dust had settled," we could appraise the situationhuman nature, sometimes at its best, at times at its worst, and often in reverse. Out of the events and incidents giving rise to the situation, the matters involved came into view and exhibited the gamut of human emotions-the hopes and fears, the cupidity, avarice, depravity, selfishness, greed and unlicensed desire to gain. All of this was shown and exhibited during the cycle of life of the main actor therein, a man who started out as Andrew Mulholland, then was George Wilson, and then by court decree about fifty years later again became Andrew Mulholland.

To obtain a correct view of what took place the background is illuminating and important.

Shortly following the Civil war there came into a rural community in eastern Iowa a stranger seeking employment. He gave his name as George Wilson. He 
was about thirty years of age, was small and wiry and walked with a slight limp. He had no relatives in that community. He secured a job on a farm; was a good worker and readily made friends. He said little of his past, but did say that he was a soldier in the Union army, and that he had been wounded at Gettysburg. He was diligent and willing, seldom left his job, and saved his earnings. He told some folks that at one time he had worked as a blacksmith. He liked to work with livestock and was particularly fond of horses. He was quite a talker and soon became known among his acquaintances as "Senator Wilson." However, he, never talked of his past, save that he was born in Pennsylvania.

\section{The Iowa Country Inviting}

About the year 1881 the writer, with his parents, went to western Iowa, then largely a prairie country, where land was cheap and soil fertile and productive. The railroad had just come in and many came to acquire and cultivate the rich, productive land. The fall following, Wilson came in on horseback to father's farm. He was riding a fine young mare and the two seemed to be close companions. He stayed a few days and then announced that he had purchased a fortyacre tract from the railroad company, about fifteen miles from where we lived. He built himself a small house, broke the prime sod and went to farming. He rented other land. A few years later he bought eighty acres adjoining. What buildings he had on the forty acres were built near the highway. His habits of talking did not change and soon the neighbors were referring to him as "Senator." He never objected to the appellation.. It was noticed, however, that at times he had a propensity to drink, what the neighbors called "hard liquor," but never even under its cheering influence, did he speak of his past.

In the vicinity there lived a farm couple who had about a dozen children, nine boys and three girls, all grown. But one was married, the oldest girl. It was 
one big family and all lived under the same roof. While the old folks owned quite a lot of land, they did little farming, renting out some of the land and pasturing stock. They lived a sort of nomad life occasionally taking off in two or three covered wagons, hunting, fishing and seeing the country, but always returning for winter. The boys always had a lot of dogs, usually coon dogs and wolf hounds. They would bring corn and grain to town and customarily the dogs were along. At night we could hear the wagons on the home with the "music" of the coon dogs quite evident. Old timers and coon dog enthusiasts say that catching coons is not so important-that they like to hear the "music" (barking) of the dogs as they follow the trail.

The oldest of the three girls married a farmer near where the "senator" lived, and a sister visiting became acquainted with him and a few years later they were married. No children were born to them. She passed away before he did.

The year prior to his marriage one evening in summer, Wilson went to the home of his neighbor just across the road. He seemed to be scared and excited and was much agitated. That afternoon the neighbor had seen three people, two men and a woman, ride by on horseback on the highway. Said Wilson to the neighbor, "Did you see those three riders?" "Yes." "Did you know them?" "No." "Did they stop?" "No." "Do you think they saw me?" "Don't know:" Wilson then asked, "What are you and the boys doing tomorrow? I have decided to move my buildings and house back from the road; can you help me move?" "Sure, we can help you out."

Pursuant to request the next day the neighbor with three of his sons went to the Wilson place. They placed skids under the house, barn and granary. Teams were attached and Wilson said he wanted the buildings moved to the "back forty," over a half mile back from the road. Wilson made no explanation, 
simply saying he wanted it done. While the neighbors wondered; still the full significance of this move did not stand revealed until about a third of a century later.

\section{SECLUDED ON THE "BACK ForTy"}

Wilson and Anna were married and for many years lived down on the "back forty." They did not take a very active part in the community life. Wilson seldom went to town and his wife did practically all the hauling. Her family had later moved to an adjoining county and bought up a lot of land, a large part of which was timbered. They still had their hounds and roved about. All the boys and the other daughter remained unmarried. A few years before Anna died she and her husband followed her people into the other county and bought a rough, gullied and timbered farm. They still kept the old farm of 120 acres.

About the turn of the century Anna passed away. Her husband continued to live on the farm, but did not seem to get along very well with her folks. While the sons were not drinking men, they felt and said that "George is a hard drinker, he spends too much for liquor." George, in turn, called the family a bunch of gypsies, loafers and dog chasers. So the breach between George and his wife's people became wide and deep.

George kept on drinking, while the sons kept dogs (twenty-five at times) and wandered and roamed. A few years later the sons purchased a merry-go-round and set up at fairs and other public gatherings. As they did all the work and spent little, they naturally accumulated quite a lot of property. All property was taken in the name of Schmidt Bros. One of them later told the writer that the läst one was to "have it all." He said they had no writing to that effect, but that "all of them understood it."

Following the death of his wife, George made trips to the cities, and while there would frequently put in time at drinking places and usually roomed at what 
might be called "flop houses." He did not return very often to the neighborhood where he first started. In time he got out of touch with old neighbors. He had no one locally to look after the farm-it was rented and the renter saw little of George.

Late one fall the tenant announced that he would have to move; that he had a letter sent from Omaha to that effect. What purported to be Wilson's signature was scrawled at the end. Some time later some folks came upon the premises, looked it over and said they wanted to rent it. A woman among them said that she owned the farm and that Wilson had deeded it to her. The tenant and some neighbors asked the whereabouts of Wilson, but got little information from any of the people. They asked her name and where she lived and got that information from her. She said Wilson had for a time stayed at her home, and that after he deeded the land to her he left and they had not seen him since.

\section{Seeking Trace of Wirson}

The suspicions of the neighbor were aroused. He made inquiries of people who lived near where Wilson lived and they had not seen him for months. Upon inquiry he found where Wilson did his banking, and there was told that some months before, Wilson had visited the bank and withdrawn all of his bank account; that he came there with some people who did not enter the bank. Among them they said was a woman and her description seemed to fit the woman who claimed to be the owner.

The neighbor at once consulted a lawyer and told him what he knew. He felt there was something wrong-possibly foul play. He suggested that the lawyer investigate. With very little to start on the lawyer stated that he would try. He investigated the place where Wilson had stayed in the city and found from the police that it had an unsavory reputation. It was reported that men would go there, get drunk and 
were robbed and some would disappear and others were run out of the country.

\section{Drinking Atrracted Dissolute Men}

By that time the deed to the 120 acres was put on record and upon examination it was found to be dated. about the same time the funds were withdrawn from the bank. They looked up the alleged notary who had acknowledged or witnessed the deed and he seemed unwilling to discuss the matter. The police were called in and they advised trying to find Wilson. They found a couple of men who were drinking companions of Wilson and they said Wilson told them he was in a jam with the rooming house people and that he did not feel safe in staying any longer. He told them that somehow these folks had found out something of his past and threatened to inform against him and that he might go to prison; that working on his fears and by threats they had forced him to deed them his property, got his bank account and left him only enough money to get out of the country; that he was leaving to start over again; that when a young man he had worked in the harvest fields of North Dakota and he felt that he would be safe there.

The next day one of these men detailed a friend to go to the depot and be on the lookout for Wilson. That evening he returned and reported that the woman who ran the rooming house and a couple of tough looking men came to the depot with Wilson, bought him a ticket, stayed with him all the time; that he acted like a man in a daze and that they put him on a train headed for the northwest. Upon inquiry at the ticket office the attorney was told that the ticket sold was for Minot, N.D. As this had happened months before it looked like a difficult task to locate the missing man.

The lawyer went to Minot and tried to discover some trace-he inquired of employment offices, threshing crews, also at cheap rooming houses. At one of the latter he found several who described a man who seemed to be the missing man-the age, general ap- 
pearance and demeanor, led the lawyer to believe he had found a trace. He was told that the man came back for a time or two later, said little except that he had worked in a harvest field with a threshing crew, but that it was hard for him on account of his age. $\mathrm{He}$ also said that an old wound which he got while in the Union army in the battle of Gettysburg bothered him. With this the lawyer felt sure they were on the right track.

\section{Located THE MISSING MAN}

Later he found where the man had worked and was told that such a man was then living in an old shack down along the river. That he was seldom about and one said, "I don't see how he lives." The attorney did not know the missing man. He wired the old neighbor to come up to be sure of the identity. He came at once and he and the lawyer went out to the shack. It was in a rugged country covered largely by small trees and brush, and there was no habitation near. The lawyer went to the door while the neighbor stayed at the car. A knock at the door got no response-a louder knock and a voice inside inquired, "Who's there-what do you want?" "I'm looking for George Wilson." "He is not here-I'm not George Wilson, go away and don't bother me." The lawyer said, "I want to see you and talk to you. I've got a man who wants you."

"My God! they are still after me after fifty years. I might as well give myself up; I'm an old man so it won't matter so much." The lawyer motioned the neighbor, who came and called, "George, open the door, it's your old neighbor; we are here to help you and to get you out of trouble. We are here to help."

Wilson opened the door to the shack and stood there shaking and unsettled. In the shack was an old mat for sleeping, a battered stove, a little table and scanty furnishings. Wilson stood there pale, haggard and emaciated.-a picture of utter hopelessness and despair. As the neighbor moved forward he stuck out 
his hand, "George, George." Wilson looked and said, "Fred, may God bless you-I am just about finishedabout finished." Fred said, "Get ready, George; we are going back; we will get your land back so that you can lead a different life." Wilson said "If I go back those folks will send me to prison; they dug up my past and I can't face it."

The lawyer inquired, "When and where did you get into trouble and what was it?" "Back a few years after the Civil war I lived in the eastern part of Iowa; I was a blacksmith; while there a gang of robbers were in hiding there. In a robbery they committed a murder; one of them was killed and the other went to prison for life. They thought I had something to do with it, and I left my wife and baby girl, changed my name and got out."

The lawyer said, "If what you did was a crime, which I doubt, under the law it is outlawed; you could not be prosecuted now for that." Wilson staggered to the old cot, sat down and buried his wan and withered face in his hands, "My God, my God, after all these years-I suffered fears and terrors-afraid to go-waiting for the law to take me in. I'll go, don't let me down or go back on me." He rose to his feet and said, "I'm ready to go; I have nothing to take along. I'll tell you about it when we get out of here. The old shack and what is in it can go-I'm through with it. Fred, you will have to take care of me until I get my property back."

\section{Fear Had Caused His Troubles}

As they made the trip back he seemed like a changed man. He told them he was an orphan, of his early life; that his true name was Andrew Mulholland; that he was in the Union army and was wounded at Gettysburg; that we went to a river town in Iowa and had a blacksmith shop and was doing very well; that he married a local girl and they had a little girl; then came on the murder, and as he had shod the horses for the bandits he heard threats and decided to leave; 
changed his name to George Wilson and went to another part of the state and started over.

"One thing that scared me was that my wife's people threatened to kill me on sight for leaving my wife and child," he said. "I knew you in the old location; you and others went to western Iowa and I decided to go there too. I rode out there on horseback and stayed the first night with Sam Mantz, whom I had known in the eastern part of the state; then as George Wilson I bought the farm across the road; that was before I married Anna. Do you remember of me getting you and the boys to help move the buildings way back from the road?"

Fred said, "Yes, I remember it; never could understand why." "Well, I'll tell you," continued George. "Those three people who rode past my place that day were my wife and two of her brothers. I wanted to call to her, but their threats to kill me wouldn't let me. Oh! if I had called; maybe she would still be living and we would know of our girl. Years later I thought of trying to locate her, but I was afraid. Then I married Anna. We lived together for many years. She used to ask about my people, but I had to lie to her-there was the old fear."

"Then I took to drinking, more and more," he related. "I would go to the city, and many a drunken orgy I went through. I went to Omaha and got a room in a cheap rooming house. Later they somehow found out my past. Two or three men threatened to inform on me-to turn me in. I was scared. Finally, they told me if I would make a deed to my property to the woman that ran the place and turned over to them my bank account, and then would leave the country, nothing further would be done. One day a man claiming to be a detective came to the house with a telegram asking if a man going under the name of George Wilson was there and saying he was wanted for a crime committed in another part of the state."

"I was paralyzed with fear and finally decided to 
do as these folks wanted. The woman brought me a deed, had me sign it, and then went with me to the bank and got my money. I was forced to stay at their home until a few days later they took me to the depot and gave me a ticket to Minot, N.D. They gave me $\$ 25.00$, and told me if I ever came back, or said a word, I'd be sorry."

When they got back to Iowa the lawyer promptly brought suit to recover the land. They sued the woman who claimed it by deed. The two men who got the bank account could not be found. When the case was tried the woman claimed that the deed was to satisfy damages against Wilson for having immoral relations with her before the deed. This she brazenly urged. In the trial the truth came out and it was shown that the woman was one of low repute, was unchaste and had sustained questionable relations with other men; also, that she had a criminal record, had frequently been in police court and that many of those who came to the place were shady and disreputable characters.

\section{Name and Property Restored}

As a witness, Wilson told of his life, his true name and his experience with the people whom the court characterized as criminals and blackmailers. The money was gone, but the real estate was restored to Wilson. The court ordered that he assume and go by his true name, Andrew Mulholland, and appointed a guardian for his property. The guardian (the writer) made application for a pension for him as a Civil war veteran. It was granted. Later Mulholland found some relatives-two grand nephews who lived in eastern Iowa. With them he spent his last years; every effort was made to find the daughter. She was traced to within about ten years of the time of the trouble. When last heard of she was in Minneapolis and Andrew thought that if living she might be in a convent. Inquiries at various convents revealed nothing.

About three years later Mulholland came to Audu- 
bon, and while talking with the guardian said that he would like to join the G.A.R. The local post had been inactive for years. The guardian hunted up three or four of the post members still living and Andrew joined as the last and final member. As the old grizzled veterans went through the solemn ritual out under a large shade tree, Mulholland's eyes brightened, and after they administered the veteran's oath and shook his hand, he said: "What I have missed; comrades, comrades, I am now one of you!"

But they did not have the bronze button to pin on his lapel. At that time the National Encampment of the G.A.R. was meeting in Des Moines, and the guardian took Andrew and another veteran to attend. $\mathrm{He}$ was taken to the statehouse and there at the G.A.R. state headquarters he was given a veteran's bronze button and proudly fastened it to his coat. The last time the guardian saw Andrew Mulholland, or George Wilson, if you please, he was standing in the rotunda of the state capitol looking at the draped battle flags, with one hand pressing and rubbing the little bronze button.

\section{Origin of Name Wisconsin}

The state of Iowa originally being largely carved from the area comprising Wisconsin territory, interest locally attaches to the current discussion in that state concerning the derivation and meaning of the name of our neighboring commonwealth. The last word upon the subject is gleaned from the 1951 edition of the Encyclopedia Americana, written by no less a personage than Dr. Wilcox, librarian of the State Historical Society of Wisconsin. He says:

"The name Wisconsin, first spelled Miskonsing then Ouisconsin by the French, was derived from the Indian name for the principal river of the region and is usually interpreted to mean 'gathering of the waters.'" 
Copyright of Annals of Iowa is the property of State of Iowa, by \& through the State Historical Society of Iowa and its content may not be copied or emailed to multiple sites or posted to a listserv without the copyright holder's express written permission. However, users may print, download, or email articles for individual use. 